TURIZAM

Volume 20, Issue 2 49-60 (2016)

ORIGINAL

SCIENTIFIC PAPER

\title{
Modelling Tourist Loyalty via Statistical Techniques
}

\author{
Oktay Emir ${ }^{A}$, Sinan Saracli ${ }^{B}$, Ramazan Ufuk Bayer ${ }^{A}$, Savas Artuğer ${ }^{C}$ \\ Received: October 2015 | Accepted: May 2016
}

\begin{abstract}
The purpose of this study is to determine the relationship between the atmospheric factors in the hotel managements and the customer loyalty. Also, this study shows the effective demographic factors on tourist loyalty. To model these effective factors; Optimal Scaling, CHAID Analysis, Explanatory Factor Analysis and Structural Equation Modelling techniques are applied. The data set is obtained from 468 Russian tourists in Antalya-Turkey between the dates June-August 2013 through questionnaire forms. As well as demographic variables, a fivepoint Likert scale is used to measure the loyalty levels of these tourists. The results of the Optimal Scaling analysis indicate that among the consumers whose loyalty is high are those more than 35 years old and those who have visited Antalya at least 2 times and those with MS or Ph.D. degrees. Loyalty levels of female consumers have been found higher than male consumers'. Numbers of visit, gender and marital status are also important factors on consumer loyalty according to the results of the CHAID analysis. Structural Equation Modelling reached to a conclusion that internal factors of hotel atmosphere are more effective on customer loyalty than external factors. Detailed results are given in related tables and figures.
\end{abstract}

Key words: consumer loyalty, hotel atmosphere, optimal scaling, CHAID analysis, structural equation modelling.

\section{Introduction}

The degree of competition is increased day by day in the hospitality industry as it shows itself in many sectors. Within this intense competition environment, hotel managements have shifted their focus from gaining new customers to retain the available ones and adopted as principle to maintain long-term business relations with the existing customers (Shoemaker and Lewis, 1999; Morgan and Rego, 2006; Pan, et al., 2012). In this context, customer loyalty has begun to

* This is an extended and unabridged version of the paper presented at TCSSE International Conference of Social Science and Education 4-6 August 2014, Cornell University, New York USA.

A Anadolu University, Faculty of Business Administration, Department of Hospitality Management Yunusemre Campus 26470, Eskisehir-Turkey, oktayemir@anadolu.edu.tr / r.ufukbayer@gmail.com

B Afyon Kocatepe University, Department of Statistics, Faculty of Arts and Sciences, Afyonkarahisar-Turkey, ssaracli@aku.edu.tr

c Muğla Sıtkı Koçman University, Tourism Faculty, Department of Travel Management, Muğla-Turkey, savasartuger@mu.edu.tr 
attract an intensive attention from both marketing practitioners and researchers starting from 1990 (Kumar and Shah, 2004; Wilkins, et al., 2010; Yoo and Bai, 2013). It is highlighted that customer loyalty has a particular importance in service industries due to its some characteristics (intangibility and inseparability-services are produced and consumed simultaneously) (Wilkins, et al., 2010). Since services are intangible, they have much more limited possibilities than goods in terms of differentiation (Pan, et al., 2012). In fact, it is underlined that marketing mixes of hotel managements $(4 \mathrm{P})$ are substantially similar and that those hotel managements who want to be different need to concentrate on customer loyalty (Passikoff, 2006). It is suggested that one of the most precious assets of hospitality managements in long term is customer loyalty (Pan, et al., 2012; Kandampully, et al., 2014). On the other hand, gaining customer loyalty in the hospitality industry is one of the biggest challenges (Bowen and Chen, 2001). Therefore, hotel executives exert great efforts in order to understand the factors that have impact on customer loyalty (Kandampully and Suhartanto, 200o; Wilkins, et al., 2010). Despite the topic of loyalty has been investigated very intensively in different industries, it is stated that hospitality industry does not pay adequate attention to this issue (Wilkins, et al., 2010).

It is known that understanding consumer behavior is not an easy task because there are many variables which has impact on consumer behaviors. Researchers in the field of environmental psychology suggest that human behaviors are greatly affected from environment (Mehrabian and Russel, 1974). In recent years, the number of studies, aiming to discover the impact of the environmental factors on consumer behaviors, have started to increase (Han and Ryu, 2009). Currently, it has begun noticed that especially the atmosphere has a great effect on consumer behavior. Within this scope, hotel managements should not focus only on traditional marketing efforts but also should made effort on making atmosphere where consumption experience is realized more desirable (Alias and Roslin, 2014).

The objective of this study is to determine the profile of the hotel customers whose sense of loyalty is higher and to investigate the relationship between atmosphere factors and customer loyalty. It is considered that this study will contribute to the literature because the topic of loyalty in the hospitality industry is studied less than those in other industries. In addition, when taking into account the necessity of studying the effects of the atmospheric factors on consumer behaviors (Alias and Roslin, 2014), it can be said that the study will provide benefit in terms of closing that gap. The study consists of five parts. In the second part of the study, the concept of customer loyalty and atmosphere and studies related to these topics were included. In the third part, the method of the study was described and findings obtained at the result of the analyses were presented. The study was finalized with the conclusion and discussion parts.

\section{Literature}

\section{Customer Loyalty}

By understanding that building long-term relationships with customers is a more effective way on the success of the hotel management rather than building short-term relationships, long-term thinking began to be adopted by the hotel managements. Within the scope of this approach, the "lifetime value" concept was started to be used and in parallel to this, the importance of customer loyalty practices was started to be understood (Shoemaker and Lewis, 1999: 346). The reason of the proliferation of this concept is the increasing competition trend in the market. As Rob Smith (1998) indicated, if the loyalty of customers can be gained, customers 
begin to call these enterprises as "our restaurant", "our hotel" and so these establishments have chance to differentiate themselves from their competitors (Shoemaker and Lewis, 1999: 349).

It is necessary to understand the concept of customer loyalty in a correct manner, which is in the center of attention within marketing environment. Loyalty can be explained very simply as; the tie between the customer who has intention to purchase from the same supplier in the future and management (Passikoff, 2006: 13). As it is realized from the explanation, customers no need to buy from the same supplier, it is enough to feel the sense of belonging towards the supplier in terms of the concept of customer loyalty. According to Oliver (1999), loyalty is defined as "deeply held commitment to re-buy or re-purchase a preferred product/service consistently in the future". According to Kandampully and Suhartanto (2000: 346), loyal customer is a customer who repurchases from the same service provider whenever possible, and who continues to recommend or maintain a positive attitude towards the service provider. On the other hand, it wouldn't be correct to interpret the loyal customers as who recommend the service provider. For example, individuals could not have the intention to visit the same destination because they will look for new experiences despite they can recommend that destination to people around them (Anton, et al., 2014: 3). There is no single universally accepted definition of loyalty as understood from these complex explanations about loyalty. According to Pan et al. (2012) who make one of the most current definition, loyalty is the degree of customers' commitment towards a product, brand or service provider and the intention of re-buy the same product/service consistently in the future. Service provides have focused on gaining loyalty of their existing customers and establishing relationships with them rather than having new customers because sustaining the loyalty of existing customers has many advantages for service providers. These are listed below (Shoemaker and Lewis, 1999; Bowen and Chen, 2001; Passikoff, 2006; Han and Ryu, 2009; Wilkins, et al., 2010; Evanschitzky, et al., 2012; Kandampully, et al. 2014);

- The probability of changing supplier is low for loyal customers,

- Loyal customers generally buy a great amount of product,

- Loyal customers generally make purchase more frequently,

- They recommend the product/service to other people,

- They attract new customers to the companies,

- Also, service provider reduces the costs and protects and increases its market share.

When the topic of loyalty is investigated conceptually, it is possible to face with different types of loyalty. Customer loyalty has two basic types as behavioral and attitudinal in the literature (Julander, et al., 1997; Anton, et al., 2014). Behavioral loyalty is the type of loyalty that corresponds only to the frequency of the customer's buying and re-buy behavior (Julander, et al., 1997; Bowen and Shoemaker, 1998; Yi and Jeon, 2003). If we look in terms of tourism, consumer behaviors such as revisiting the same destination by tourists (McKercher, Denizci-Guillet, \& Ng, 2012) and repeat guests of the hotels are the examples for behavioral loyalty. However, critics have been made to state that behavioral loyalty is insufficient while explaining loyalty in the following years (Bowen and Chen, 2001; Han and Ryu, 2009; Kandampully, et al., 2014). When investigating customer loyalty, it is suggested to take into account not only behaviors but also psychology and emotions of the customers. In other words, it cannot be said that consumers who continue to buy from the same service provider are loyal definitely. Attitudinal loyalty completes the deficiency of behavioral loyalty. Attitudinal loyalty means a positive attitude that includes the customers' commitment towards the service providers, intention of repurchase and recommendation to other people (Julander et al., 1997; Oliver, 1997; Kumar and Shah, 2004; Anton, et al., 2014). It is seen in tourism that first the behavioral loyalty was measured in studies addressing cus- 
tomer loyalty, and in studies published in the forthcoming years, that the attitudinal loyalty was measured because it reflects loyalty better (Toyama and Yamada, 2012). In this study, the attitudinal approach is adopted when measuring loyalty of hotel customers.

In the literature, conceptual studies about the loyalty issue are quite often. For example, Shoemaker and Lewis (1999) have conducted a study for understanding the concept of customer loyalty. In addition, Kandampully, et al. (2014), with their study where they presented a review summary related to the issue, they demonstrated the existing knowledge and new developments about customer loyalty. Yoo and Bai (2013) addressed the development and change of the customer loyalty issue in the hospitality industry. Besides these conceptual studies, also quantitative researches are included in the literature. Kandampully and Suhartanto (200o) studied the effect of hotel image and customer satisfaction on customer loyalty in their study conducted with the sample of hotel customers and obtained the result that food and beverage, reception, housekeeping and price dimensions have important effects on customer loyalty. Bowen and Chen (2001) studied the relationship between satisfaction and loyalty of hotel customers and providing room according to room preference (i.e., non-smoking), check-in and check-out procedures are the factors that mostly affecting customer loyalty. Pan, et al. (2012), investigated the effect size of some variables on loyalty of hotel customers, they clustered these variables into two groups as customer-related factors (satisfaction, trust, commitment, loyalty program membership) and product-related factors (product quality, perceived value, switching costs, brand reputation). In this study, although these two dimensions have a significant effect on customer loyalty, it was observed that particularly trust of the customer-related factors was more effective than the others.

\section{Atmosphere}

Studies on the subject of atmosphere have a long history and it is seen that different definitions are made regarding the atmosphere within this period. Despite atmosphere was tried to be described by many researchers until now, it is stated that its conceptual meaning is still ambiguous (Heide and Grønhaug, 2006: 273). Kotler (1973) defines atmosphere as "the atmosphere of a particular set of surroundings is describable in sensory terms" and highlights mainly the environmental aspect of the concept. According to Bitner (1992), the atmosphere is expressed as "total configuration of environmental dimensions". Atmosphere is described by Darley and Gilbert (1995) as the physical factors which can be controlled by managements in order to improve the responses of employees and customers towards the management. Hoffman and Turley (2002) describe the atmosphere as the combination of tangible and intangible elements that make up the essence of the experience. Heide and Grønhaug (2006) express that the atmosphere is established at the result of interaction between individuals and their surroundings.

Atmosphere is an important factor considered when assessing the experience of consumers. It is known that atmosphere has a more critical role particularly for services. Atmosphere is more precious in services rather than goods because the clues that consumers will assess the service are limited and this limitation occurs from the intangible nature of the services (Nguyen and Leblanc, 2002). In addition, since production and consumption is realized simultaneously in services, consumers are exposed to environmental factors where the service is produced, and this characteristic of services makes the atmosphere more important (Bitner, 1992; Heide and Grønhaug, 2006; Heide and Grønhaug, 2009). Kotler (1973) draws attention to that atmosphere can be important too in the purchasing decisions of consumers besides itself of the basic product. In the forthcoming years, it was suggested that sometimes atmosphere 
can pass in front of the basic product for services beyond stated by Kotler (1973). For instance, customers can perceive the atmosphere in some restaurants more important than the food itself as suggested by Heide and Grønhaug (2009). Similar to the example of restaurant, partially parallel discoursing can be accepted correct in terms of hotels. Hotels are not enterprises that meet only the need of accommodation of customers but also they are experience providers which offer atmospheres that affect the customers' emotions (Chen, et al., 2014).

The components of atmosphere are in fact stimulants that affect both existing and future behaviors of consumers and consequently consumer responses (approach or avoidance) (Mehrabian and Russell, 1974). Similarly, atmosphere in the management and marketing literature is expressed as an important tool used to shape consumers' attitudes and behaviors (Heide and Grønhaug, 2006). In this context, it is seen that researchers handle the relationship between loyalty and atmospheric factors in different fields. For example, according to the results of the study of Harris and Ezeh (2008) conducted with restaurant customers in the U.K., the atmospheric dimensions such as cleanliness, aesthetic appeal and staff customer orientation are the dimensions having the highest relationship with customer loyalty and the atmospheric dimension that has the highest relationship with loyalty is physical attractiveness of the staff. According to the results of the study conducted by Lee, et al. (2008) with the visitors participated in the international dance festival in Korea, loyalty has a significant and indirect relationship with its components (comfortable, layout, atmosphere etc.) in the festival and emotions have the role of mediating variables there. In another study, the relationship between environmental factors (i.e., décor and artifacts, spatial layout, and ambient conditions), price perception, customer satisfaction and customer loyalty has been investigated in restaurant businesses (Han and Ryu, 2009). In this multi-dimensional study, the relationship of the subject with the dimensions of price and customer satisfaction has been dealt together. The results of the study suggest that physical evidences constitute a significant effect on loyalty through the mediating variable of price perception. Heide and Grønhaug (2009) investigated the relationship between the atmospheric dimensions of hotels and service outputs such as customers' satisfaction, intensions of recommendation and revisiting, and the result showed that the most basic atmospheric dimension that explain the service outputs in hotels was hospitability. In another study, the relationship between the dimensions of service quality (food and beverage, service experience and physical product), perceived value, customer satisfaction and loyalty has been gauged together and it has been found out that the physical product mostly predicts loyalty indirectly (Wilkins, et al., 2010). Other than restaurants and hotels, there are also studies that measure the relationship between loyalty of customers visiting shopping malls and the atmosphere of shopping mall. Alias and Roslin (2014) demonstrated that the atmosphere explains $37.6 \%$ of the variance with the intention of loyalty in line with data obtained from customers visiting one of the most popular shopping malls in Malaysia.

\section{Methodology}

Questionnaire method has been chosen as data gathering method. In the 1st part, 6 questions on demographic features have been asked. In the 2nd part, 6 questions on loyalty, 9 questions on internal hotel variables, 6 questions on external hotel variables and finally 5 questions on the influence of hotel staff on customer loyalty have been asked. The 2nd part of the questionnaire has been created by analyzing similar studies (Kandampully and Shurtanto, 20oo; Bowen and Chen, 2001; Han and Ryu, 2009; Sperdin and Peters, 2009; Musa and Thirumoor- 
thi, 2011; Kim, et al., 2012) and both the content and the comprehensibility of the questionnaire have been controlled by taking experts' opinion.

Questions have been graded by a five-point Likert scale. Grading has been done ranging from 1 (strongly disagree) to 5 (strongly agree). Russian tourists, who came to Antalya district in 2013, took part in the questionnaire. Sampling size has been calculated by $(\mathrm{N}>10000)$ suggested by Özdamar (2001) and by $n=\sigma^{2} \cdot Z_{\sigma}^{2} / H^{2} \sigma^{2} \cdot Z_{\sigma}^{2} / H^{2}$ formula recommended for quantitative studies. Sampling size has been calculated as 400 but, considering the invalid questions, 700 people have been sampled. After subtracting invalid questionnaires, 468 questionnaires have been taken into evaluation.

\section{Results}

In this part, first the descriptive statistics are included, which demonstrate the demographic characteristics of individuals attending the survey. Then, findings for Optimal Scaling, CHAID, EFA and SEM analyses are presented respectively. Descriptive statistics about demographic features have been given in Table 1.

Table 1. Descriptive statistics of respondents

\begin{tabular}{|c|c|c|c|}
\hline Variable & Category & Frequency & Percentage \\
\hline \multirow{2}{*}{ Gender } & Male & 171 & 63.5 \\
\hline & Female & 297 & 36.5 \\
\hline \multirow{2}{*}{ Marital Statue } & Single & 240 & 51.3 \\
\hline & Married & 228 & 48.7 \\
\hline \multirow{5}{*}{ Age } & Under 24 & 132 & 28.2 \\
\hline & $25-34$ & 158 & 33.8 \\
\hline & $35-44$ & 103 & 22.0 \\
\hline & $45-54$ & 38 & 8.1 \\
\hline & Over 55 & 37 & 7.9 \\
\hline \multirow{4}{*}{ Education Level } & Primary school & 73 & 15.6 \\
\hline & Secondary school & 119 & 25.4 \\
\hline & Faculty & 181 & 38.7 \\
\hline & Master's Degree & 95 & 20.3 \\
\hline \multirow{5}{*}{ Number of Visit } & First time & 271 & 57.9 \\
\hline & 2 & 122 & 26.1 \\
\hline & 3 & 32 & 6.8 \\
\hline & 4 & 32 & 6.8 \\
\hline & 5 and over & 11 & 2.4 \\
\hline \multirow{6}{*}{ Length of stay } & 1-3 days & 27 & 5.8 \\
\hline & 4- 6 days & 138 & 29.5 \\
\hline & 7-9 days & 109 & 23.3 \\
\hline & $10-13$ days & 107 & 22.9 \\
\hline & 14-16 days & 77 & 16.5 \\
\hline & Over 17 days & 10 & 2.1 \\
\hline
\end{tabular}


Some important statistics for the consumers' demographic features can be listed as: While $63.5 \%$ of the participants are female, $36.5 \%$ of them are male. On the other hand, $51.3 \%$ of the participants are single and $48.7 \%$ of them are married. Most of them are younger than 34 years old. Most of them obtain at least a university degree. For most of the Russian tourists' participated in this survey, length of stay is between 4 and 13 days. Results of Optimal Scaling Analysis are given in Figure 1. The output of Optimal Scaling Analysis is presented in the two-dimensional plane. Dimension 1 and 2 which refer two axes in Figure 1, cannot be specified because these are not specific parameters.

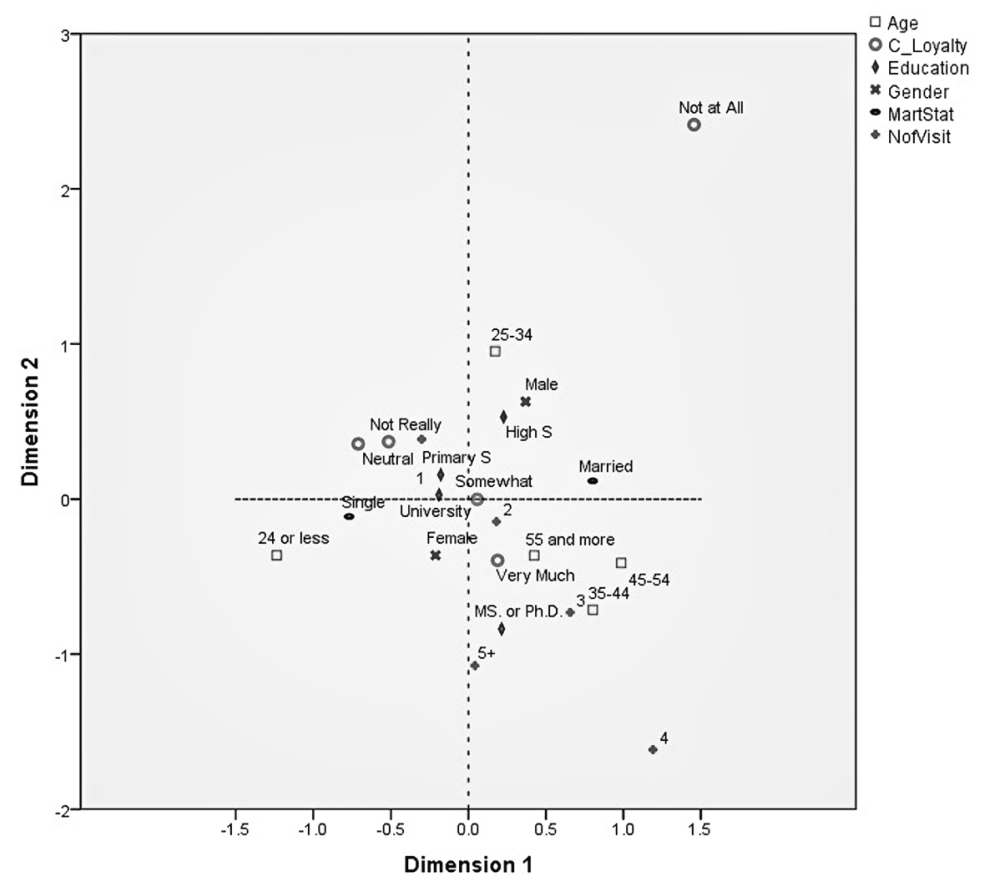

Figure 1. Output of the Optimal Scaling Analysis

When we examine the results of Optimal Scaling (Multiple Correspondence) analysis, we see that among the consumers who are more loyal are those who are, older than 35 those who have visited at least 2 times Antalya and those who have MS or Ph.D. degrees. In addition, we can say that female customers are more loyal than the male consumers. The Results of CHAID Analysis are given in Figure 2.

The results of the CHAID analysis indicate that the most important variable on consumer loyalty is the number of visits. The highest loyalty levels among these customers have the customers who visited the same hotel four times. Gender is also a significant factor and it can be seen that females are much loyal than the males. Furthermore, marital status is another important factor among the customers who visited the same place at least 4 times and married customers are considered to be more loyal. 


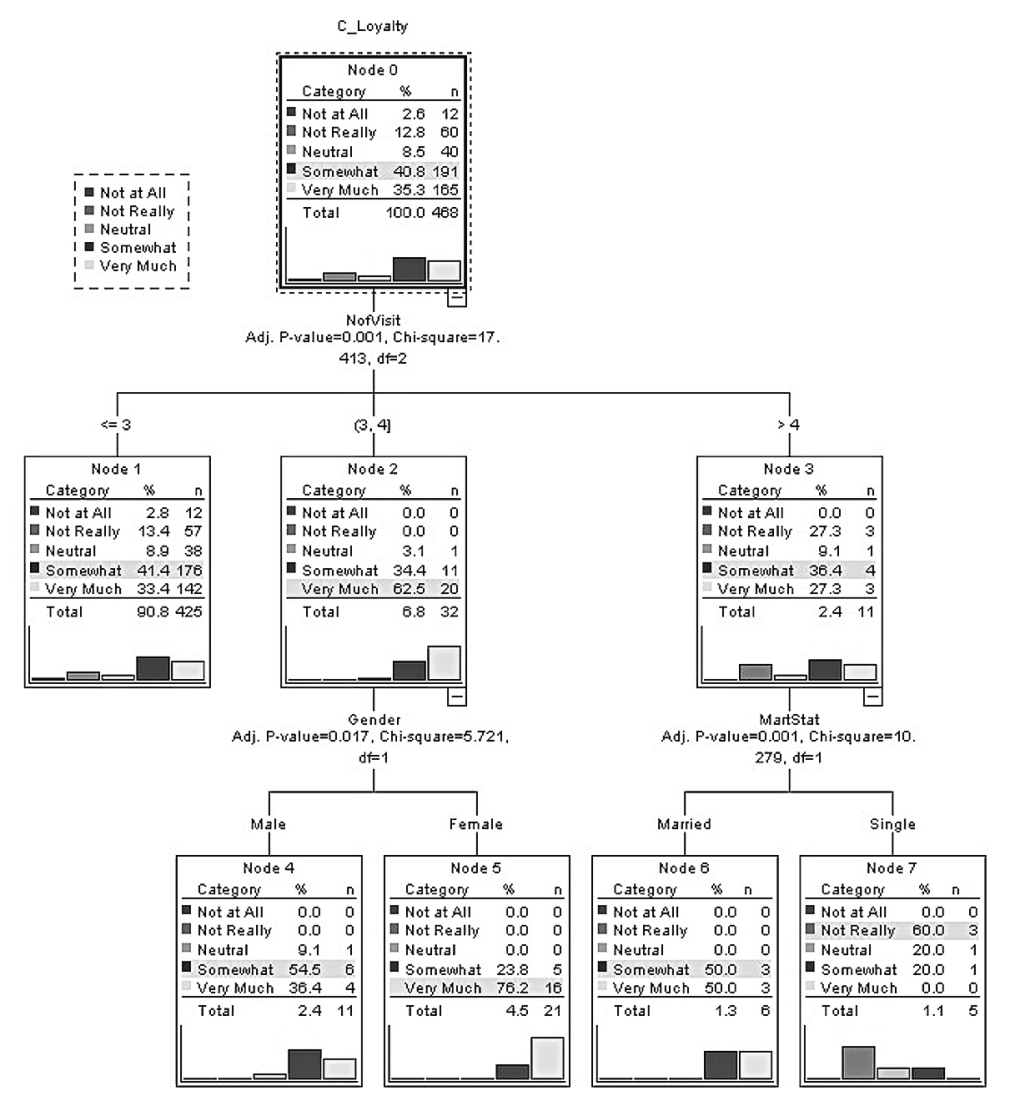

Figure 2. Results of the CHAID Analysis

\section{EFA Results}

As a result of EFA, we obtained three factors; Internal Factors, External Factors and Customer Loyalty. EFA results also show that the total variance explanation ratio for three factors is $63.7 \%$, which is sufficient enough. The factor loadings, Eigen values of each factor, and Cronbach's Alpha values are given in Table 2.

\section{SEM Results}

Results of the SEM and the goodness of fit statistics are given in Figure 3 and Table 3 respectively. In Figure 3 abbreviations corresponds to:

IF: Internal Factors,

EF: External Factors and

CL: Customer Loyalty

According to Table 3, all of the model indices for our model are between the limits of perfect and acceptable fitness.

The results of the SEM indicate that Internal Factors are more efficient on Customer Loyalty than External Factors with the coefficients of 0.26 and 0.14 respectively. While Variable I2 (Nice music has been played in the hotel) has the highest effect within Internal Factors with 
Table 2. Results of Explanatory Factor Analysis

\begin{tabular}{|c|l|c|c|c|c|}
\hline Factors & & Loadings & Eigenvalues & $\%$ of variance & $\alpha$ \\
\hline IF & INTERNAL FACTORS & & 2,447 & 20,394 & 0,857 \\
\hline I1 & $\begin{array}{l}\text { Great importance was given to colour } \\
\text { compatibility in common areas }\end{array}$ & 0.854 & & & \\
\hline I2 & Nice music has been played in the hotel & 0.916 & & & \\
\hline I3 & $\begin{array}{l}\text { Pleasant smell surrounds the rooms and common } \\
\text { areas }\end{array}$ & 0.842 & & 28.257 & 0.834 \\
\hline EF & EXTERNAL FACTORS & & 3.391 & & \\
\hline E1 & Signposts are placed at correct places & 0.771 & & & \\
\hline E2 & Hotel's architecture is impressive & 0.819 & & & \\
\hline E3 & Hotel has vast green areas and gardens & 0.820 & & & \\
\hline E4 & Landscape arrangements of hotel is pleasant & 0.807 & & & \\
\hline E5 & $\begin{array}{l}\text { Hotel's entrances are designed to ease going in } \\
\text { and outs }\end{array}$ & 0.651 & & & \\
\hline CL & CUSTOMER LOYALTY & & & \\
\hline L1 & $\begin{array}{l}\text { I prefer stay in at this Hotel even if the prices are } \\
\text { increased a bit }\end{array}$ & 0.657 & & & \\
\hline L2 & $\begin{array}{l}\text { Despite the problems I may encounter, I prefer } \\
\text { this establishment }\end{array}$ & 0.823 & & & \\
\hline L3 & This hotel is my priority preference & $\begin{array}{l}\text { As long as I can, I will come back to this hotel in } \\
\text { the future }\end{array}$ & 0.668 & & \\
\hline
\end{tabular}

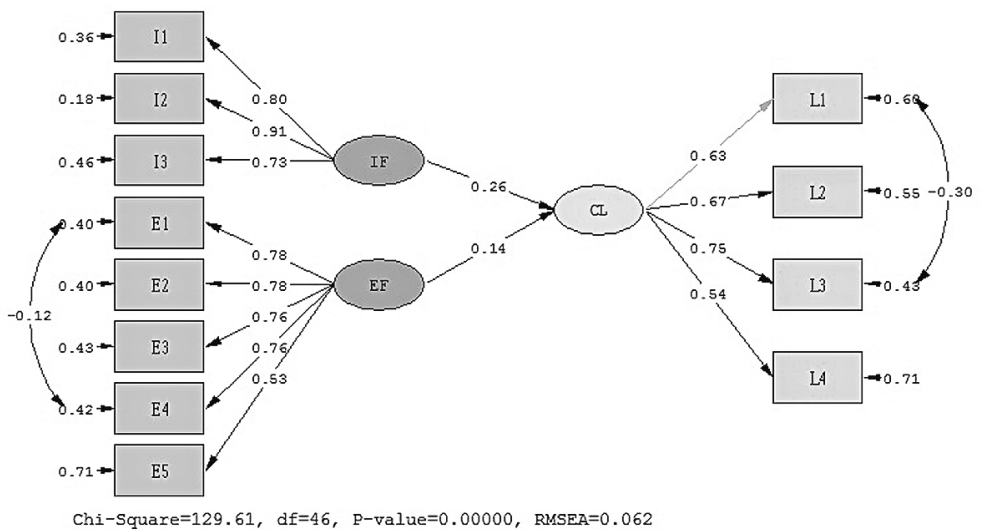

Figure 3. Structural Model for the Consumer Loyalty

Table 3. Goodness of Fit Indices for the Structural Model

\begin{tabular}{|c|c|c|c|}
\hline Criteria & Perfect Fitness & Acceptable Fitness & Model \\
\hline RMSEA & $0<\mathrm{RMSEA}<0.05$ & $0,05 \leq \mathrm{RMSEA} \leq 0,10$ & 0,062 \\
\hline $\mathrm{NFI}$ & $0.95 \leq \mathrm{NFI} \leq 1$ & $0.90 \leq \mathrm{NFI} \leq 0.95$ & 0.940 \\
\hline $\mathrm{NNFI}$ & $0.97 \leq \mathrm{NNFI} \leq 1$ & $0,95 \leq \mathrm{NNFI} \leq 0,97$ & 0.940 \\
\hline $\mathrm{CFI}$ & $0.97 \leq \mathrm{CFI} \leq 1$ & $0.95 \leq \mathrm{CFI} \leq 0.97$ & 0,960 \\
\hline $\mathrm{GFI}$ & $0.95 \leq \mathrm{GFI} \leq 1$ & $0.90 \leq \mathrm{GFI} \leq 0.95$ & 0.940 \\
\hline $\mathrm{AGFI}$ & $0.90 \leq \mathrm{AGFI} \leq 1$ & $0.85 \leq \mathrm{AGFI} \leq 0.90$ & 0,910 \\
\hline
\end{tabular}


the coefficient of 0.91, variables E1 (Signs are efficient enough) and E2 (Hotel's architecture is impressive) has the highest effect within External Factors with the coefficient of 0.78 . On the other hand, variable $\mathrm{L}_{3}$ (This hotel is my priority preference) is found most effective on Customer Loyalty with the coefficient of 0.75 among other exogenous variables.

\section{Conclusion and Discussion}

The effect of the atmospheric components of the hotel on customer loyalty is investigated in this study. The result of the study demonstrated that the atmospheric factors of hotels have a significant effect on customer loyalty. It was noted that the effect of particularly the internal factors of the atmospheric factors were greater than the external factors of the atmosphere. In other words, the factors regarding the internal dimension of the atmosphere such as the music played at the hotel, the colors used in the hotel, and smells in the rooms and common areas are more effective than the external factors (signposts, architecture, landscape arrangements, etc.) on customer loyalty. It can be said that these results are parallel with the results of the study of Wilkins, et al. (2010). In their study, customer loyalty is measured together with the mediator variable of customer satisfaction and their study reveal that physical product (colors, lobby, ambiance, room quality) makes the greatest effect on customer satisfaction directly and on customer loyalty indirectly. It is considered that internal atmospheric factors are more effective than the external factors because hotel guests are spending most of their time in the hotel during their stay and expose to the internal environment more.

Other than the atmosphere and its effect on loyalty, the profile of the customers who have higher level of loyalty has been demonstrated in this study. The findings of the study indicate that the number of visit criteria is an important determinant of the loyalty behavior. In particular, the loyalty levels of tourists staying in the same hotel 4 times or more is higher than the others. Therefore, developing loyalty requires repeated behaviors. Just as mentioned in learning theory, repeating behaviors play an important role in realization of the learning process. This result indicates also the relationship between behavioral and attitudinal loyalty. It can be inferred that behavioral loyalty has an effect on attitudinal loyalty. Other than visit frequency, it is understood that the demographic variables such as gender, marital status and educational background are effective indicators of the customers' loyalty level. According to the result of this research, the best loyal tourist profile can be described as female tourists who have higher education background, older than 35 years old and married is significantly higher than other tourists.

The results of this study indicate that consideration must be showed to the atmospheric factors of hotels, in particular to the internal ones in order to increase customer loyalty. Hotel managements who want to have more loyal customers should take into account both the making improvements for the atmospheric factors and targeting right customer profile. For example, showing high loyalty by those of the hotel customers having a lower educational background, single, young and male is not a logical expectation. Simply, hotels that want to have more loyal customers should also take into account the demographic characteristics of the target customer group. It is possible to make recommendations also for researchers other than the industry practitioners. Sample of this study is consisting of only the Russian tourists and researchers interested in the subject can investigate whether there is any difference associated with the nationality of the tourists through including tourists with different nationalities in their samples. In addition, data used in this study was collected in the high touristic season. 
Dependency on season intensity can be assessed in the future studies by collecting data in the low touristic season. In addition to these, validity of the results can be tested by analyzing the same subject using qualitative methods such as interview and focus group interview.

\section{References}

Alias, Z. \& Roslin, R. M. 2014. The Mediating Role of Experiential Values on Servicescape Strategies and Loyalty Intention of Department Store Customers in Malaysia. Proceeding for International Conference of Asian Marketing Association (ICAMA), C o n s u m p t i o n Trends in Asian Markets, March 13-15, 2014, Seoul, Korea.

Anton, C., Camarero, C. \& Garcia, M. L. 2014. Towards a new approach of destination loyalty drivers: satisfaction, visit intensity and tourist motivations, Current Issues in Tourism, 1-24.

Bitner, M. 1992. Servicescapes: the impact of physical surroundings on customers and employees, Journal of Marketing, 56(2), 57-71.

Bowen, J. T., \& Chen, S. 2001. The relationship between customer loyalty and customer satisfaction. International Journal of Contemporary Hospitality Management, 13(5), 213-217.

Chen, Y. C., Yu, T. H., Tsui, P. L. \& Lee, C. S. 2014. A fuzzy AHP Approach to Construct International Hotel Spa Atmosphere Evaluation Model. Qual Quant, 48, 645-657.

Darley, J.M. \& Gilbert, T.G. 1985. Social Psychology, in Handbook of Social Psychology ～(3rd Ed.). Gardner Lindzey and Elliot Aronson, eds. New York: Random House, Inc

Evanschitzky, H., Ramaseshan, B., Woisetschläger, D.M., Richelsen, V., Blut, M. \& Backhaus, C. 2012. Consequences of customer loyalty to the loyalty program and to the company. Journal of the Academy of Marketing Science, 40(5), 625-638.

Han, H. \& Ryu, K. 2009. The roles of the physical environment, price perception, and customer satisfaction in determining customer loyalty in the restaurant industry, Journal of Hospitality \& Tourism Research, 33(4), 487-510.

Harris, L. C. \& Ezeh, C. 2008. Servicescape and Loyalty Intentions: An Emprical Investigation. European Journal of Marketing. 42(3-4), 390-422.

Heide, M. \& Grønhaug, K. 2006. Atmosphere: Conceptual Issues and Implications for Hospitality Management. Scandinavian Journal of Hospitality and Tourism, 6(4), 271-286.

Heide, M. \& Grønhaug, K. 2009. Key Factors in Guests' Perception of Hotel Atmosphere. Cornell Hospitality Quarterly, 50(1), 29-43.

Hoffman, K.D. \& Turley, L.W. 2002. Atmospherics, service encounters and consumer decision making: an integrative perspective. Journal of Marketing Theory and Practice, 10(3), 33-47.

Julander, C., Magi, A., Jonsson, J. \& Lindqvist, A. 1997. Linking customer satisfaction to financial performance data. In B. Edvardsson, S. W. Brown, R. Johnston, \& E. E. Scheuing (Eds.), Advancing service quality: A global perspective (pp. 301-310). Karlstad, Sweden: University of Karlstad.

Kandampully, J. \& Suhartanto, D. 200o. Customer Loyalty in the Hotel Industry: The Role of Customer Satisfaction and Image. International Journal of Contemporary Hospitality Management, 12 (6), 346-351.

Kotler, P. 1973. Atmospherics as a marketing tool. Journal of Retailing, 49(4), 48-64.

Kumar, V. \& Shah, D. 2004. Building and Sustaining Profitable Customer Loyalty for the 21st Century. Journal of Retailing, 80, 317-330.

Lee, Y. K., Lee, C. K., Lee, S. K. \& Babin, B. J. 2008. Festivalscapes and Patrons' Emotions, Satisfaction and Loyalty. Journal of Business Research, 61, 56-64. 
McKercher, B., Denizci-Guillet, B., \& Ng, E. 2012. Rethinking loyalty. Annals of Tourism Research, 39, $708-734$.

Mehrabian, A. \& Russell, J.A. 1974. An Approach to Environmental Psychology. Cambridge, MA: MIT Press.

Morgan, N.A. \& Rego, L.L. 2006. The value of different customer satisfaction and loyalty metrics in predicting business performance. Marketing Science, 25(5), 426-439.

Musa, G. \& Thirumoorthi, T. 2011. Red palm: Exploring service quality and servicescape of the best backpacker hostel in Asia, Current Issues in Tourism, 14.(2), 103-120.

Nguyen, N. \& Leblanc, G. 2002. Contact personnel, physical environment and the perceived corporate image of intangible services by new clients. International Journal of Service Industry Management, 13, 242-262.

Oliver, R. L. 1999. Whence customer loyalty? Journal of Marketing, 63, 33-44.

Özdamar, K. 2001. Multivariate Data Analysis and Package Softwares (4 ${ }^{\text {th }}$ Edition), Eskişehir, Kaan Publications.

Pan, Y., Sheng, S. \& Xie, F.T. 2012. Antecedents of customer loyalty: an empirical synthesis and reexamination. Journal of Retailing and Consumer Services, 19(1), 150-158.

Passikoff, R. 2006. Predicting Market Success. New Ways to Measure Customer Loyalty and Engage Customers with Your Brand. New Jersey: Wiley.

Shoemaker, S. \& Lewis, R. C. 1999. Customer Loyalty: The Future of Hospitality Marketing. International Journal of Hospitality Management, 18, 345-370.

Sperdin, A. B. \& Peters, M. 2009. What influences guests' emotions? The case of high-quality hotels, International Journal of Tourism Research, 11, 171-183.

Toyama, M. \& Yamada, Y. 2012. The Relationships among Tourist Novelty, Familiarity, Satisfaction and Destination Loyalty: Beyond the Novelty-familiarity Continuum. International Journal of Marketing Studies, 4(6), 10-18.

Wilkins, H., Merrilees, B. \& Herington, C. 2010. The Determinants of Loyalty in Hotels, Journal of Hospitality Marketing \& Management, 19(1), 1-21.

Yi, Y. \& Jeon, H. 2003. Effects of loyalty programs on value perception, program loyalty, and brand loyalty. Journal of the Academy of Marketing Science, 31(3), 229-240.

Yoo, M. \& Bai, B. 2013. Customer Loyalty Marketing Research: A comparative Approach between Hospitality and Business Journals. International Journal of Hospitality Management, 33, 166-177. 